Warszawskie Studia Pastoralne UKSW

Rok X 2015 Nr 4 (29)

Zofia KęPIŃSKa-WALCZAK

\title{
THREATS TO LOVE: FR. JÓZEF TISCHNER'S REFLECTIONS
}

In his reflections, Father Józef Tischner devoted much attention to love - one of the three theological virtues, constituting the foundations of Christianity. He described the characteristics of love and warned against the threats to love a number of times. According to Tischner, love constantly encounters many dangers and needs to face them in order to save its authenticity. There are threats that seem to accompany love all the time, creeping to its farthest corners, trying to destroy what is the purest and most true in love. Where love is, often selfishness and envy appear. Betrayal and hatred destroy love. A danger also arises when man confuses love with some different kind of emotion, namely when lust sneaks in to his relationship with the other person. Another threat is a temptation that Abraham experienced, a temptation which makes us abandon the value of what is closest to us for the supreme value. In this paper, various dangers are discussed that pose a threat to love, according to Fr. Tischner. The paper also attempts to indicate how these threats can be overcome.

\section{Envy}

Envy is a major cause of human wrongdoing towards one another. The Bible gives numerous examples showing its destructive force. Envy was the source of Cain's $\sin ^{1}$. Cain could not bear the knowledge that his brother might surpass him at something. It's envy that made Joseph's brothers want to kill Joseph and sell him into slavery ${ }^{2}$. Also,

1 Cf. Gen 4: 1-16.

2 Cf. Gen 37: 11. 
Herod was driven by envy, and he did not hesitate to murder the babies of Bethlehem in his attempt to kill Jesus ${ }^{3}$. These examples show that envy can push man to the worst deeds.

Even today, envy often underlies the human sin. It is a specific kind of hatred, directed against those who have something one desires, or against those who are the kind of person one wants to be. "Envy hates the neighbour, not because they are evil, but because they are good or even better than us. In fact, envy hates the good, unless it belongs to the envy" . Envy distorts the perception of the world. It causes suffering not only to those who are the object of envy, but also to the ones who are filled with envy. "Envy casts suspicions, accusations, it continually strives to 'unmask' others, it will not rest until it 'proves'

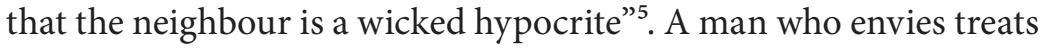
the other person objectively, the neighbour is there to meet his needs only, the neighbour is a means to his ends. Where there is envy, no true love can flourish.

\section{Lust}

Lust is a danger that primarily threatens the love of a man and a woman. This kind of love requires special care, because "the original sin has deeply distorted the human sexuality, in that it separated sexuality from the basic hope to have offspring and start a family". Without that hope, sexuality is stripped of love and begins to serve lust. To better understand this danger, we must first consider what lust is.

According to Tischner, "desires are born somewhere in the depths of human sexuality"7. Desire is looking for an object that could bring satisfaction. "Desire is a principle of action. The paradox of this principle lies in the fact that, in the case of desires, the experience of

3 Cf. Mt 2: 16-18.

4 J. Tischner, Pomoc $w$ rachunku sumienia [An Assist in the Examination of Conscience], Kraków 2009, p. 23.

5 Ibid.

6 Ibid, pp. 30-31.

${ }^{7}$ J. Tischner, Spór o istnienie człowieka [The Controversy Over the Existence of Man], Kraków 2001, p. 72. 
lack instantaneously triggers action"8. Desires are the expression of sexuality, their satisfaction brings pleasure ${ }^{9}$, which, in turn, gives rise to another desire. Consequently, the purpose of pleasure becomes the pleasure itself. Man falls into a vicious circle. "Love no longer opens man to the 'Other' - God and neighbour - who are out of his interests, but makes him focus on his own frightened Self"10. What was hitherto love, has lost the very attributes of love. Love is no longer selfless, but boastful and irritable, it seeks its own advantage, it is rude and arrogant. Love becomes merely a "delight" of satisfying one's desires. What underlies such a "distorted love" is the fear of being open to offspring. In fact, it is simply a fear of responsibility ${ }^{11}$. It can no longer be called love, but the appearance of love.

Lust reduces love to eroticism, which enslaves the human being. True love, on the other hand, allows man to be free. "Love is a phenomenon that transcends sexuality. Erotic attraction may fade away, but love can last"12. If, however, there is nothing between the two people except for eroticism and lust mistakenly interpreted as love, then such a relationship will be a mutual enslavement. In time, eroticism and lust will pass, and there will remain nothing to keep these two people together.

\section{The temptation of Abraham}

The biblical story of Abraham and Isaac reveals a dangerous temptation which appears in the human heart. "The beginning of the story of Abraham and Isaac seems to suggest that God expects us to love Him with the kind of love that is absolute, exclusive, a love that fills us entirely, to the point where there is no more room for love to

8 Ibid, p. 77.

9 Cf. Ibid.

10 J. Tischner, Pomoc $w$ rachunku..., op. cit., p. 31.

11 Cf. Ibid, p. 32.

12 Przekonać Pana Boga. Z ks. Józefem Tischnerem rozmawiają Dorota Zańko i Jarosław Gowin [To Convince God. Dorota Zańko and Jarosław Gowin's conversation with Fr. Józef Tischner] , Kraków 1999, p. 179. 
other people, to our neighbour"13. However, this is not what love is about. God does not want such a sacrifice. God does not expect man to unhesitatingly sacrifice the value of what is closest to him for the supreme value. Can true love expect such a dramatic choice from the beloved? In fact, this kind of sacrifice is a crucial temptation present in every religion and faith. This temptation is even more dangerous in that it "somehow corresponds to the human nature. Our hearts are not very spacious, there is no room for a larger group of neighbours. A new emergent feeling takes the place of the old one"14. Interestingly, man is more willing to sacrifice a person close to him than his enemy. Tischner draws attention to the fact that "the greatest conflicts in human history erupted not between non-believers, but between believers in the same God. (...) It is as if one believer identified himself with Abraham and treated the other believer as Isaac, who needs to be sacrificed, put on the altar"15. It is only with the help of God's love, and with reference to it, that man is able to fight this temptation in himself. People often misunderstand the story of Abraham, and as a result they become indignant at God's cruelty. They throw up their hands, because they can't find any meaning in the story. According to Tischner, however, it was all about Abraham's temptation who might have understood what God said to him too subjectively. "Everyone speaks in their own language, every one of us translates every word of others into the language of their own imagination. And so did Abraham try to translate God's call into his own imagination"16. Tischner notes that, reading this passage of the Bible, we have good enough reason to believe that God did not require Abraham to kill his son, but that Abraham misunderstood the meaning of God's call.

13 Wokół Biblii. Z ks. Józefem Tischnerem rozmawia Ewelina Puczek [Around the Bible. Ewelina Puczek's conversation with Fr. Józef Tischner], Kraków 2005, p. 35.

14 Ibid, p. 36.

15 Ibid.

16 J. Tischner, J. Żakowski, Tischner czyta Katechizm [Tischner Reads the Catechism], Kraków 1997, p. 34. 


\section{Hate}

Another threat to love, or, in fact, its contradiction, is hate. Similarly to love, hate also manifests itself in various ways. To speak of hate, we need to first look at its various types. There is a kind of hate that is not evil, but directed against evil, against anything that "is unfair, destructive and depriving people of hope"17. Obviously, this kind of hate is not a threat to love. Rather, it testifies about the human inner strength. It invokes the wrath for evil. This kind of anger was experienced by Jesus when he saw people trading instead of praying in the temple ${ }^{18}$. Such anger is fully justified and is a sign of the love for goodness and holiness. "There is, thus, a kind of hate that results from the deep human love for the sacred and precious, a hate which springs from the depths of human love for what is noble and worthy: this is the other face of love"19. Such hate is not only permissible, but rather, it is everyone's duty.

The kind of hate that threatens love is directed at a human person. Such hate cannot be justified in any way. It is this type of hatred that the Pharisees harbored against Christ. Such hate "told them to track Christ day after day (...). It was a flame that kept them awake at night, that drained their strength. It was an invisible bond linking the fate of the hated with the fate of the hating. Whoever happened to fall into the circle of this deep hatred, found himself in a world of struggle and destruction" ${ }^{20}$. Undoubtedly, Pharisees' hate was great. Such hate gives rise to the passion of destroying $\operatorname{man}^{21}$.

However, apart from great hatreds, there are also little hatreds. Such hate was demonstrated by the indifference of Pilate, who was "too miserable to be able to hate anyone, and too cowardly to tie his fate with the fate of a man hated by others"22. He did not want

\footnotetext{
J. Tischner, Jak żyć? [How to Live], Wrocław 1990, p. 223.

${ }^{18}$ Cf. J 2: 13-17.

19 J. Tischner, Jak $\dot{z} y c ́$ ?, op. cit., p. 223.

20 Ibid, p. 224.

${ }^{21}$ Cf. Ibid.

22 Ibid.
} 
to have anything to do with Christ ${ }^{23}$, and yet he contributed to the crucifixion of the Messiah. The cross of Christ is a work of a great and little hatred ${ }^{24}$.

These two kinds of hatred - a great and a little one- continually appear in the history of mankind until the present day. Great hatreds have given death sentences on people a number of times throughout history; little hatreds either carried out these sentences with cold indifference, or did not respond at all. Indifference kills in the same way as the flare of hatred. "Indifference is also a hatred, but a hatred of miserable people who are too afraid to show enough strength"25.

The hate towards the human person can never be justified. It is always a sin against love. And always reaches farther than we might think. We should be aware that when Christ found himself in the world of hatred, inflicted upon him by the Pharisees, this hatred affected also his work, his vocation, the meaning of his sacrifice, and every one of us. As Christ was hated, so were we somehow (...) To destroy Christ, meant to destroy me as well" ${ }^{\text {26 }}$. Similarly, if someone feels hatred, even someone unknown to us and living in the other hemisphere, their hatred reaches us too. We cannot love some people and hate others at the same time. There are no exceptions. When man becomes aware of the enormous devastation caused by hate, when he notices the spiral of evil initiated by one act of hatred, then he himself will admit that love is a principle that should govern human relationships, always and everywhere.

\section{Betrayal}

Betrayal, which is the fruit of hate, is another danger threatening love. Tischner claims that "in the Gospels there actually appears one sin only: the sin of betrayal. Betrayal reveals the entire human hatred"27.

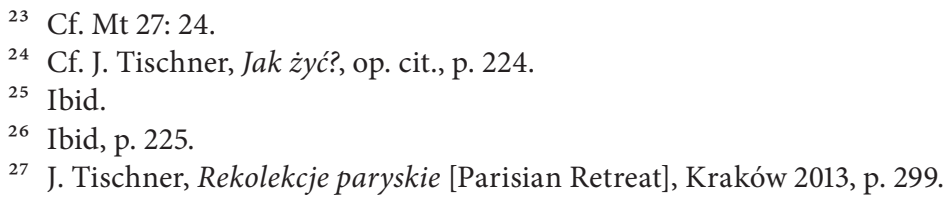


Betrayal is infidelity. "Only the one can betray who knows what faithfulness is" 28 . Virtually all sins boil down to infidelity. In Christianity, infidelity constitutes the synthesis of all evil. To betray God, to betray man - is the largest sin that man can commit. If religion is a bond, a bond of fidelity, then betrayal is the breaking of that bond ${ }^{29}$.

As in the case of hate, we can also distinguish between a great and a little betrayal. An example of a great betrayal is the betrayal of Judas, who gave the Fair away to die ${ }^{30}$. Little betrayals involve daily, often overlooked and underestimated matters, such as being late, or failing to keep a given word ${ }^{31}$. It happens that someone consciously lets betrayal in to their relationship with the other person. This happens when one says to another: "we will be together for as long as happiness unites us; when this is over, each of us will go search for a new happiness. Betrayal is an expression of freedom and the price that we pay for temporary happiness" ${ }^{32}$, if permanent happiness seems to be beyond our reach. Such an attitude is characterized by vigilance of some sort as well as fear of making sacrifices and facing difficulties. The acceptance of betrayal coincides here with the desire to possess the other person ${ }^{33}$. All of this stands in stark contrast to love, which neither sets conditions, nor wants to possess the beloved.

Reflecting on betrayal, we have to touch upon the betrayal in a marriage. Tischner notices what follows: "Marriage is the two people in one flesh. Physical intimacy creates an incredible closeness. Betrayal does not only break the spiritual, but also physical reciprocity" ${ }^{34}$. This entails far-reaching, dramatic consequences and inflicts great pain to love.

\footnotetext{
28 J. Tischner, Filozofia dramatu [The Philosophy of Drama], Kraków 2012, p. 256.

29 Cf. J. Tischner, Rekolekcje paryskie, op. cit., p. 315.

30 Cf. Przekonać..., op. cit., p. 178.

31 Cf. Rekolekcje paryskie, op. cit., p. 317.

32 J. Tischner, Świat ludzkiej nadziei [The World of Human Hope], Kraków 1994, p. 95 .

33 Cf. Ibid, p. 96.

34 Przekonać..., op. cit., p. 178.
} 
Betrayal, whether great or little, expresses the entire hatred towards the human being ${ }^{35}$.

\title{
Conclusion
}

The phenomena described in this paper are real threats to love. Envy is a source of suffering and pushes man to the worst deeds. Lust gives rise to selfishness and enslaves the human being. There also appears a temptation in the human heart to kill one love for the sake of another. Hatred towards man evokes passion to destroy him. Finally, there is betrayal, which expresses the whole hatred for the human being. Where any of the above appears, no real love can flourish. But, at the same time, it is the true love that can conquer these threats. It is therefore necessary to nurture love, to continually strive to follow evangelical love in our human loves. This is the only way we can overcome threats to love. It's about reaching to the sources, about returning to the Gospels.

\begin{abstract}
In his reflections, Father Józef Tischner devoted much attention to love - one of the theological virtues, which constitute the foundations of the Christian life. He wrote not only about what love and its characteristics are, but also about threats to love. This paper discusses the various dangers associated with love, and concludes that the only thing that can conquer these dangers is love itself. Therefore, we should cherish love all the time, following the example of evangelical love.
\end{abstract}

Keywords: fr. Józef Tischner, love, threats to love, envy, lust, the temptation of Abraham, hate, betrayal

Zofia Kępińska-Walczak, mgr teologii, doktorantka teologii pastoralnej na UKSW, absolwentka Instytutu Wiedzy o Kulturze (obecnie: Instytut Dialogu Kultury i Religii) na UKSW w Warszawie, wolontariuszka w Stowarzyszeniu Rodzin i Opiekunów Osób z Zespołem Downa „Bardziej Kochani”, zainteresowania naukowe: religijność ludowa, duszpasterstwo nadzwyczajne,

35 Cf. J. Tischner, Rekolekcje paryskie, op. cit., p. 299. 
personalizm chrześcijański.

Kontakt zofia_kepinska@wp.pl

\section{Bibliografia:}

Tischner J., Filozofia dramatu, Kraków 2012.

Tischner J., Jak żyć?, Wrocław 1990.

Tischner J., Pomoc w rachunku sumienia, Kraków 2009.

Przekonać Pana Boga. Z ks. Józefem Tischnerem rozmawiaja Dorota Zańko i Jarosław Gowin, Kraków 1999.

Tischner J., Rekolekcje paryskie, Kraków 2013.

Tischner J., Spór o istnienie człowieka, Kraków 2001.

Tischner J., Świat ludzkiej nadziei, Kraków 1994.

J. Tischner, J. Żakowski, Tischner czyta Katechizm, Kraków 1997.

Wokół Biblii. Z ks. Józefem Tischnerem rozmawia Ewelina Puczek, Kraków 2005. 